\title{
Huwe1 is a novel mediator of protection of neural progenitor L2.3 cells against oxygen-glucose deprivation injury
}

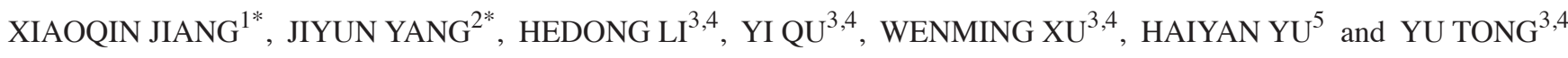 \\ ${ }^{1}$ Department of Anesthesiology, West China Second Hospital, Sichuan University; ${ }^{2}$ Center for Human Molecular Biology \\ and Genetics, Institute of Laboratory Medicine, The Key Laboratory for Human Disease Gene Study of Sichuan, \\ Sichuan Academy of Medical Sciences and Sichuan Provincial People's Hospital; ${ }^{3}$ Department of Pediatrics, \\ West China Second University Hospital; ${ }^{4}$ Key Laboratory of Birth Defects and Related Diseases of Women and Children, \\ Ministry of Education; ${ }^{5}$ Department of Obstetrics and Gynecology, West China Second Hospital,
}

Sichuan University, Chengdu, Sichuan 610041, P.R. China

Received December 22, 2017; Accepted July 25, 2018

DOI: $10.3892 / \mathrm{mmr} .2018 .9430$

\begin{abstract}
Hypoxic-ischemic encephalopathy is one of the most notable causes of brain injury in newborns. Cerebral ischemia and reperfusion lead to neuronal damage and neurological disability. In vitro and in vivo analyses have indicated that E3 ubiquitin protein ligase (Huwe1) is important for the process of neurogenesis during brain development; however, the exact biological function and the underlying mechanism of Huwe1 remain controversial. In the present study, neural progenitor cells, L2.3, of which we previously generated from rat E14.5 cortex, were used to investigate the role of Huwe1 and its effects on the downstream N-Myc-Delta-like 3-Notch1 signaling pathway during oxygen-glucose deprivation (OGD). To evaluate the role of Huwe1 in L2.3 cells, transduction, cell viability, lactate dehydrogenase, 5-bromo-2'deoxyurine incorporation, western blotting and immunocytochemical assays were performed. The results of the present study indicated that Huwe1 rescued L2.3 cells from OGD-induced insults by inhibiting proliferation and inducing neuronal differentiation. In addition, Huwel was suggested to mediate the survival of L2.3 cells by inhibiting the activation of the N-Myc-Notch1 signaling pathway. Of note, the effects of Huwe1 on Notch1
\end{abstract}

Correspondence to: Dr Yu Tong, Department of Pediatrics, West China Second University Hospital, Sichuan University, 21 Renmin Nan Road, Section 3, Chengdu, Sichuan 610041, P.R. China

E-mail: zisu_yu@163.com

Dr Haiyan Yu, Department of Obstetrics and Gynecology, West China Second Hospital, Sichuan University, 21 Renmin Nan Road, Section 3, Chengdu, Sichuan 610041, P.R. China

E-mail: fanjy422@163.com

"Contributed equally

Key words: E3 ubiquitin protein ligase, neural progenitors L2.3 cells, oxygen-glucose deprivation, N-Myc-Delta-like 3-Notch1 signaling pathway signaling were completely abolished by knockdown of N-Myc, indicating that Huwel may require N-Myc to suppress the activation of the Notch1 signaling in L2.3 cells. The determination of the neuroprotective function of the Huwe1-N-Myc-Notch1 axis may provide insight into novel potential therapeutic targets for the treatment of ischemic stroke.

\section{Introduction}

Hypoxic-ischemic encephalopathy is a type of brain injury within newborns, in which cerebral ischemia and reperfusion lead to neuronal damage and neurological disability $(1,2)$. Increasing evidence has suggested that neuronal injury induces the proliferation and differentiation of neural stem cells/progenitor cells (NSCs/NSPs) and adult neurogenesis (3-5). NSPs possess a notable ability to self-renew and differentiate into glia and functional neurons $(6,7)$. Animal and clinical studies (8) have suggested that NSPs are a powerful potential treatment for numerous diseases of the central nervous system (9-11). Specifically, it has been reported that NSPs are involved in the regeneration of neurons and glia during perinatal hypoxia/ischemia (H/I) (12).

Numerous signaling pathways are involved in the regulation of NSCs (13-16). N-Myc, which is mainly distributed in the developing nervous system, is predominantly expressed in NSCs and neuroectodermal progenitors under normal conditions $(17,18)$. In addition, $\mathrm{N}-\mathrm{Myc}$ is required for the development of the nervous system; loss of N-Myc function results in the failure of neural progenitor cell expansion (19). Notch signaling has been associated with the regulation of NSCs; the Notch signaling pathway promotes the survival and proliferation of normal and tumor-derived NSCs, and prevents their differentiation (20-22). Binding of the ligands Delta or Jagged to Notch receptors induces the intramembranous proteolytic cleavage of the Notch receptor, yielding an activated Notch intracellular domain (NICD), which is necessary for the regulation of the transcription of several target genes, such as fibroblast growth factor 5 (23).

By using mass spectrometry, E3 ubiquitin protein ligase (Huwe1), containing a HECT domain, was purified from H1299 
cells transfected with a plasmid expressing HA-ARF-Flag (24). Huwe1 has numerous substrates, including N-Myc, p53 and cell division cycle 6 (25-29). It has been demonstrated that Huwe1 is important for the transition from NSCs/NSPs to differentiated neurons (27). Loss of Huwe1 severely disrupts neurogenesis and the laminar organization in the cortex and, interestingly, the N-Myc-Delta-like 3 (DLL3)-Notch1 signaling cascade has been reported to be involved in this process $(27,30)$. In vitro and in vivo research has indicated that Huwel is a key factor for neurogenesis; however, the exact biological function and underlying mechanism of Huwe1 remains controversial: Huwel affects the accumulation of many substrates, including $\mathrm{N}-\mathrm{Myc}, \mathrm{c}-\mathrm{Myc}$ and Mcl1, which are involved in carcinogenesis. However, Huwel also promotes the accumulation of p53 protein, which inhibits the growth and development of multiple cancer types.

We previously generated neural progenitor L2.3 cells from a rat E14.5 cortex with the ability to differentiate into neurons, astrocytes, oligodendrocytes and other neuronal cell types $(31,32)$. In the present study, radial glial L2.3 cells were used to investigate the role of Huwel and the downstream N-Myc-DLL3-Notch1 signaling pathway during oxygen-glucose deprivation (OGD) and the restoration of normal conditions.

\section{Materials and methods}

Cell culture. The culturing conditions of L2.3 cells were described previously (32). Briefly, L2.3 cells were cultured as neurospheres for 3 to 4 days in culture medium: Dulbecco's modified Eagles medium/F12 (Invitrogen; Thermo Fisher Scientific, Inc., Waltham, MA, USA) supplemented with $25 \mathrm{mM}$ glucose (Sigma-Aldrich; Merck KGaA, Darmstadt, Germany), $2 \mathrm{mM}$ glutamine, 100 units/ml penicillin and $0.1 \mathrm{mg} / \mathrm{ml}$ streptomycin (both Invitrogen; Thermo Fisher Scientific, Inc.), $10 \mathrm{ng} / \mathrm{ml}$ fibroblastic growth factor 2 (FGF2; BD Biosciences, San Jose, CA, USA), $2 \mu \mathrm{g} / \mathrm{ml}$ heparin (Sigma-Aldrich; Merck KGaA) and 1X B27 (Invitrogen; Thermo Fisher Scientific, Inc.). Cells were propagated as neurospheres and passaged by mild trypsinization $(0.025 \%$ for $5 \mathrm{~min}$ at $37^{\circ} \mathrm{C}$ with $\left.5 \% \mathrm{CO}_{2}\right)$ every 3 days. Cells $\left(1 \times 10^{4}\right)$ were cultured on laminin-coated coverslips in $10 \mathrm{ng} / \mathrm{ml}$ FGF2-containing serum-free culture medium (DMEM/F12 with $25 \mathrm{mM}$ glucose, $2 \mathrm{mM}$ glutamine, 100 units $/ \mathrm{ml}$ penicillin, $0.1 \mathrm{mg} / \mathrm{ml}$ streptomycin, $10 \mathrm{ng} / \mathrm{ml} \mathrm{FGF} 2,2 \mu \mathrm{g} / \mathrm{ml}$ heparin and $1 \mathrm{X} \mathrm{B} 27$ ) for 2 days at $37^{\circ} \mathrm{C}$ prior to transduction with a lentiviral vector (described below). For differentiation, cells were cultured on laminin-coated coverslips in $10 \mathrm{ng} / \mathrm{ml}$ FGF2-containing serum-free medium for 1 day, then the medium was replaced with FGF2-free culture medium with fetal bovine serum (1\%) (Gibco; Thermo Fisher Scientific, Inc.) for 5 days. The cells were then fixed and stained with specific antibodies as described below.

Establishment of the OGD-injured L2.3 cell model. OGD was conducted to induce $\mathrm{H} / \mathrm{I}$ in vitro. Cells $\left(\sim 1 \times 10^{4}\right)$ were washed three times with glucose-free culture medium (DMEM/F12 with $2 \mathrm{mM}$ glutamine, 100 units/ml penicillin

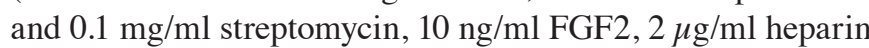
and $1 \mathrm{X} \mathrm{B} 27$ ) prior to oxygen deprivation and placed in an anaerobic chamber, then perfused with $\mathrm{N}_{2}(95 \%)$ and $\mathrm{CO}_{2}(5 \%)$ at $37^{\circ} \mathrm{C}$ for $6 \mathrm{~h}$. Following OGD, the cells were transferred to the aforementioned culture medium and cultured with $\mathrm{CO}_{2}$ $(5 \%)$ at $37^{\circ} \mathrm{C}$ for the normalization of oxygen and glucose levels for 8,16 and $24 \mathrm{~h}$. Cells cultured under normoxic conditions were considered the control group.

Lentiviral constructs and transduction. GIPZ lentiviral microRNA-adapted short hairpin (sh)RNA vectors (sequences unavailable; expressing control non-silencing shRNA, rat Huwel shRNA and N-Myc shRNA, respectively) were obtained from Open Biosystems, Inc. (Thermo Fisher Scientific, Inc.). In accordance with the Trans-Lentiviral packaging system (Open Biosystems, Inc.; Thermo Fisher Scientific, Inc.), lentiviral packaging was conducted using 5.0x10 ${ }^{5}$ TLA-293T cells (Open Biosystems; GE Healthcare Dharmacon, Inc., Lafayette, CO, USA). The DMEM/F12 medium containing the packaging plasmids was aspirated and replaced with complete medium (DMEM/F12 containing 20\% FBS) $12 \mathrm{~h}$ following transfection. The cell supernatant, containing the lentivirus was collected after $72 \mathrm{~h}$, centrifuged at $12,000 \mathrm{xg}$ and $4^{\circ} \mathrm{C}$ for $20 \mathrm{~min}$ and stored at $-80^{\circ} \mathrm{C}$. To determine the titers of lentiviral particles in the isolated supernatants, TLA-293T cells were transduced with serial dilutions $(5 \mathrm{X}, 10 \mathrm{X}, 20 \mathrm{X})$ of the lentiviral supernatants $\left(500 \mathrm{x} \mathrm{g}\right.$ at $4^{\circ} \mathrm{C}$ for $\left.10 \mathrm{~min}\right)$ for $48 \mathrm{~h}$ and were identified by green fluorescent protein fluorescence and sorted on a BD FACS Aria II (BD Biosciences). As determined by trypan blue staining technique, the viability of cells after cell sorting was higher than 95\%. (33) (x4 magnification, $488 \mathrm{~nm}$ excitation). L2.3 cells were transduced with lentiviral particles (Huwel shRNA or Huwel shRNA and N-Myc shRNA) diluted $(2 \mathrm{X}, 5 \mathrm{X})$ in serum free medium containing $10 \mu \mathrm{g} / \mathrm{ml}$ of Polybrene ${ }^{\circledR}$ (Merck KGaA) at a multiplicity of infection (MOI) of 10, all carrying green fluorescent protein (GFP). After $6 \mathrm{~h}$, an equal amount $(1 \mathrm{ml})$ of culture medium was added to each well. The transduction cocktail was removed and replaced with complete medium containing puromycin (2 $\mu \mathrm{g} / \mathrm{ml}$ ) the following day, and western blot analysis for Huwe1 and N-Myc expression in cell lysates was performed to select for Huwe1 shRNA-transfected cells or Huwel and N-Myc shRNA-transfected cells. Control shRNA-transfected cells and untransfected cells were used as the controls.

Cell viability assay. A Cell Counting Kit-8 (Dojindo Molecular Technologies, Inc., Kumamoto, Japan) was used to assess cell viability: $100 \mu 1$ of the L2.3 cell suspension (in PBS) was seeded in 96-well plates $(50,000$ cells/well). Untransfected cells were used as the control. The kit was utilized according to the manufacturer's protocols; the absorbance at $450 \mathrm{~nm}$ was measured with a microplate reader (Bio-Rad Laboratories, Inc., Hercules, CA, USA). Cell viability was calculated by setting the absorbance of the normoxic control to $100 \%$.

Lactate dehydrogenase $(\mathrm{LDH})$ release assay. $\mathrm{LDH}$ release in the culture medium was measured using an LDH diagnostic kit (Nanjing Jiancheng Bioengineering Institute, Nanjing, China), according to the manufacturer's protocols. LDH activity was calculated in 96 -well plates $\left(5 \times 10^{4}\right.$ cells/well) by measuring the absorbance at $490 \mathrm{~nm}$ with a microplate reader (Bio-Rad Laboratories, Inc.). 
A

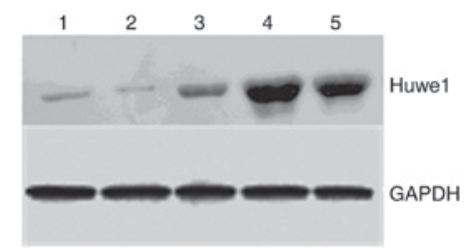

C

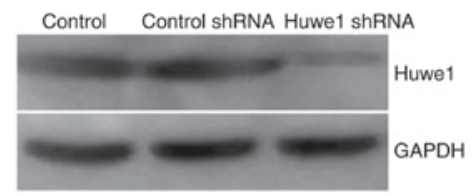

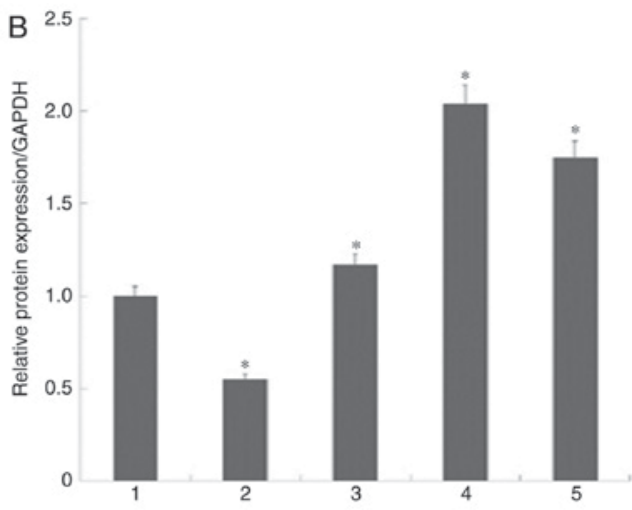

$\mathrm{E}$

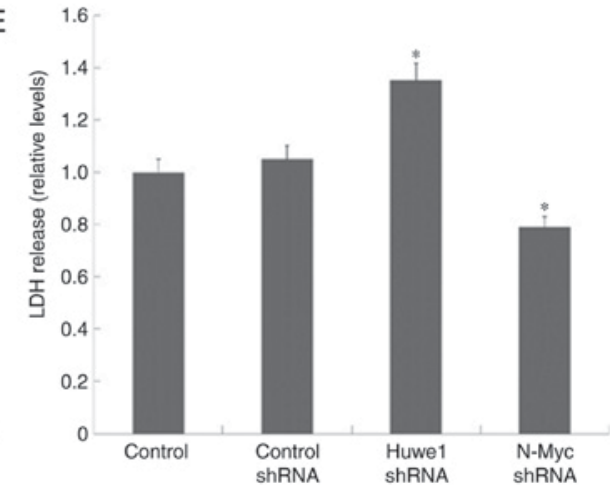

Figure 1. Huwe1 rescues L2.3 cells from OGD-induced injury. (A) Representative western blot analysis of Huwe1 expression in L2.3 cells. 1, Prior to OGD exposure; 2. OGD for $6 \mathrm{~h} ; 3$, following OGD for $6 \mathrm{~h}$ and restoration for $8 \mathrm{~h} ; 4$, following OGD for $6 \mathrm{~h}$ and restoration $16 \mathrm{~h}$; and 5 , following OGD for $6 \mathrm{~h}$ and restoration for $24 \mathrm{~h}$. (B) Quantification of Huwel protein expression levels, which were normalized to GAPDH. ${ }^{*} \mathrm{P}<0.05$ vs. prior to OGD exposure (line 1 ). (C) Huwe1 protein expression levels were detected in control L2.3 cells and L2.3 cells transduced with viral particles containing control shRNA or Huwe1 shRNA. (D) Cell viability and (E) LDH levels in culture medium. The data were presented as the mean \pm standard error. Data were obtained from three independent experiments. ${ }^{*} \mathrm{P}<0.05$ vs. control and control shRNA groups. Huwe1, E3 ubiquitin protein ligase; LDH, lactate dehydrogenase; OGD, oxygen-glucose deprivation; shRNA, short hairpin RNA.

5-bromo-2'deoxyurine (BrdU) assay. Cells were treated with $10 \mu \mathrm{M}$ BrdU (Roche Diagnostics, Sussex, UK) for $24 \mathrm{~h}$. Spheres were dissociated with $10 \mathrm{mg} / \mathrm{ml}$ collagenase for $10 \mathrm{~min}$ at room temperature and $\sim 2 \times 10^{4}$ cells were fixed with a formalin solution for $15 \mathrm{~min}$ at $37^{\circ} \mathrm{C}$ on a Matrigel-coated coverslip (incubated overnight with Matrigel at $37^{\circ} \mathrm{C}$ ). Following permeabilization with PBS containing Triton X-100 $(0.1 \%)$ at room temperature for $30 \mathrm{~min}$, DNA denaturation was performed with $2 \mathrm{~N} \mathrm{HCl}$ for $10 \mathrm{~min}$ at room temperature, followed by neutralization with $0.1 \mathrm{M}$ sodium tetra-borate for $10 \mathrm{~min}$ at room temperature. The subsequent steps conducted were described below in 'Immunocytochemistry'. Genome-integrated BrdU was detected using an anti-BrdU antibody (1:200; cat. no 555627; BD Biosciences) and a Cy3 conjugated anti-mouse secondary antibody (1:1,000; cat. no. 115-165-003; Jackson ImmunoResearch Laboratories, Inc., West Grove, PA, USA). The proportion of BrdU positive cells relative to the total number of cells was estimated using a fluorescent microscope (x10 magnification, $550 \mathrm{~nm}$ excitation). Three fields of view were analyzed.

Immunocytochemistry. L2.3 cells underwent expansion for 5 days under normal conditions or following OGD. Cells $\left(2 \times 10^{4}\right)$ were fixed in paraformaldehyde $(4 \%)$ at room temperature for $15 \mathrm{~min}$. The primary antibodies employed were: Mouse anti-nestin (1:200; cat. no. MAB5326; Merck KGaA) or rabbit anti-microtubule-associated protein 2 (MAP2; 1:100; cat. no. M3696; Sigma-Aldrich; Merck KGaA). Following incubation at $4^{\circ} \mathrm{C}$ overnight, the cells were washed and incubated with the appropriate secondary antibodies at $37^{\circ} \mathrm{C}$ for $1 \mathrm{~h}$, including fluorescein isothiocyanate goat anti-mouse secondary antibody (cat. no. ab6785; 1:1,000; Abcam, Cambridge, USA), Сy3 goat anti-rabbit secondary antibody (cat. no. BA1032; 1:500; Wuhan Boster Biological Technology, Ltd., Wuhan, China). Cell nuclei were counterstained with 4',6-diamidino-2phenylindole (DAPI, Sigma-Aldrich, 1:10,000, USA, cat. no. D9564) at $37^{\circ} \mathrm{C}$ for $30 \mathrm{~min}$, using a fluorescent microscope (x100 magnification, $359 \mathrm{~nm}$ excitation). Three fields of view were analyzed using a fluorescent microscope (Nikon Tie).

Western blot analysis. Cells were lysed with SDS lysis buffer [50 mM Tris ( $\mathrm{pH} 8.1$ ), 1\% SDS, $2 \mathrm{mM}$ sodium pyrophosphate, $25 \mathrm{mM} \beta$-glycerophosphate, $1 \mathrm{mM}$ EDTA, $1 \mathrm{mM} \mathrm{Na}_{3} \mathrm{VO}_{4}$ and $0.5 \mu \mathrm{g} / \mathrm{ml}$ leupeptin] and heat-denatured at $95^{\circ} \mathrm{C}$ for $5 \mathrm{~min}$. Protein concentration was measured with a bicinchoninic acid protein assay. Cellular proteins $(20 \mu \mathrm{g} /$ lane $)$ were separated via SDS-PAGE (10\%) and transferred to polyvinylidene difluoride membranes. The membranes were blocked for $1 \mathrm{~h}$ with blocking buffer at room temperature (1X PBS with $0.1 \%$ Tween 20 and 5\% non-fat dry milk) and then incubated with primary antibodies against Huwe1 (1:500; cat. no. ab701612; Abcam), Notch1 (1:200; cat. no. sc6014; Santa Cruz Biotechnology, Inc., Dallas TX, USA), NICD 


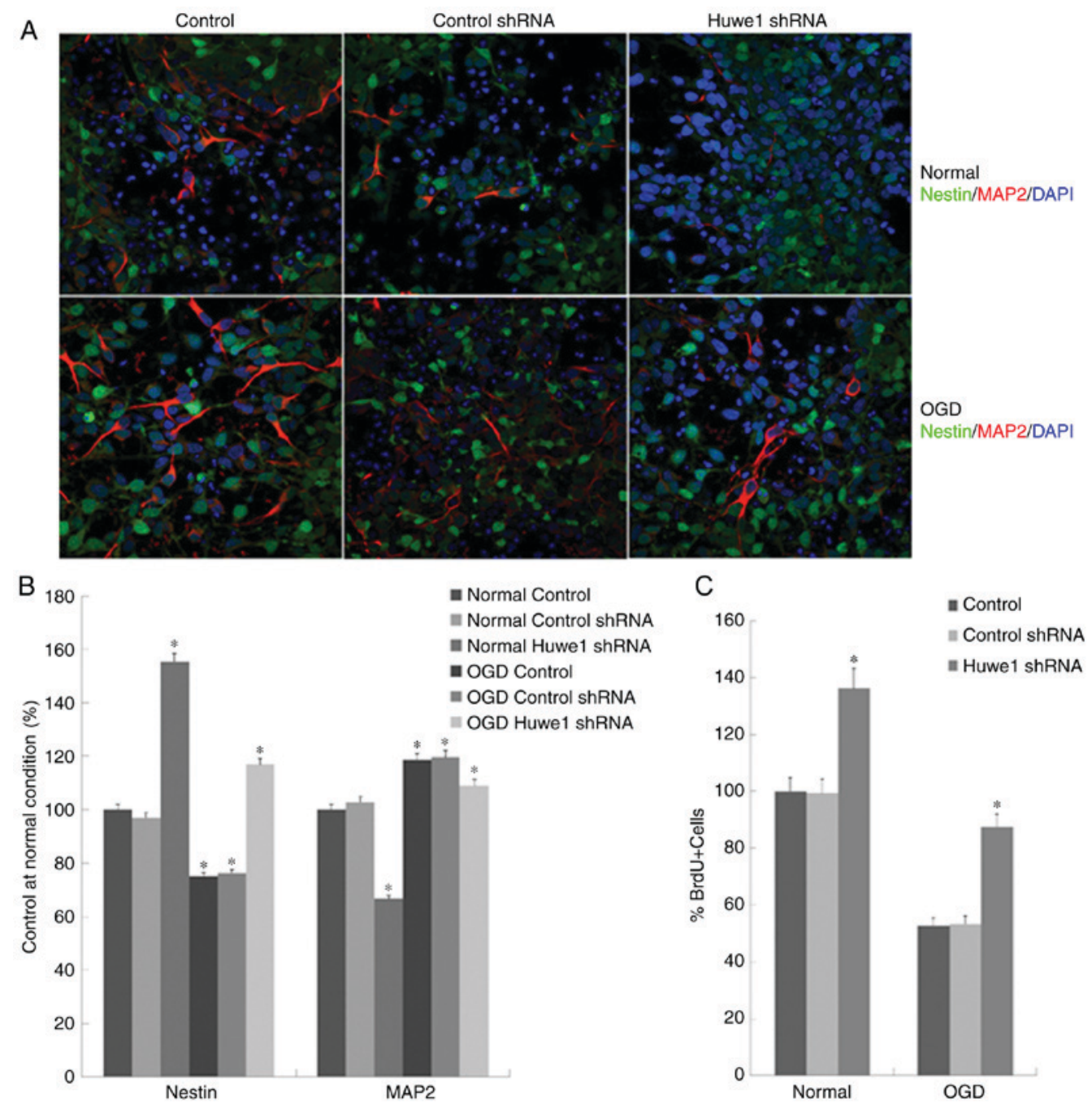

Huwe1 shRNA

Figure 2. Huwe1 inhibits proliferation and induces the neuronal differentiation of L2.3 cells. (A) Representative immunocytochemical images of nestin (green), MAP2 (red), DAPI (blue) staining of L2.3 cells that underwent expansion for 5 days under normal conditions or following OGD. (B) Quantification of fluorescence. (C) BrdU incorporation assay. The proportion of mitotically active cells reduced under OGD and increased with cells transduced with shRNA against Huwe1; the number of cells in each condition was normalized to the control conditions. Data are presented as the mean \pm standard error from more than three independent experiments. " $\mathrm{P}<0.05$ vs. the normal control. BrdU, 5-bromo-2'deoxyurine; Huwe1, E3 ubiquitin protein ligase; MAP2, microtubule-associated protein 2; OGD, oxygen-glucose deprivation; shRNA, short hairpin RNA.

(1:1,000; cat. no. AB8925; Cell Signaling Technology, USA), DLL3 (1:200, Abcam, USA, cat. no. ab103102), N-Myc (1:200; cat. no. ab24193) at $4^{\circ} \mathrm{C}$ overnight, and then with anti-rabbit horseradish peroxidase-conjugated secondary antibody $\left(1: 1,000\right.$; cat. no. ab6721; Abcam) at $37^{\circ} \mathrm{C}$ for $1 \mathrm{~h}$. The blots were developed using an enhanced chemiluminescence detection system (Merck KGaA). An anti-GAPDH antibody (mouse IgG; cat. no. ab70699; 1:1,000; Abcam) was used to detect GAPDH and normalize the sample loading. The western blot image was analyzed by Bio-Rad Image Lab 4.1 (Bio-Rad Laboratories, Inc.). Experiments were performed three times.

Statistical analysis. For comparisons among multiple groups, one-way analysis of variance followed by Fisher's Least Significant Difference method was performed to determine the statistical differences between groups by using the SPSS 15.0 software. All data were expressed as the mean \pm standard deviation of three experiments. $\mathrm{P}<0.05$ was considered to indicate a statistically significant difference.

\section{Results}

Huwel knockdown decreases cell viability after $6 h$. We previously reported that, upon the onset of OGD, the viability of L2.3 cells progressively decreased; the cell number was significantly lower after $6 \mathrm{~h}(\mathrm{P}<0.001, \mathrm{n}=3)$ (34). Accordingly, in the present study, $6 \mathrm{~h}$ was selected as the duration of OGD. To investigate whether Huwel serves a key role in OGD, the expression levels of Huwe1 in L2.3 cells exposed to OGD for $6 \mathrm{~h}$ were determined, followed by the restoration of normal conditions at 8, 16 and $24 \mathrm{~h}$ (Fig. 1A). Quantification of Huwe1 protein expression levels were normalized to GAPDH (Fig. 1B). The results revealed that the expression levels of Huwe1 were significantly increased in OGD-treated L2.3 cells compared with cells unexposed to OGD.

To evaluate the role of Huwel in L2.3 cells, GIPZ shRNA lentiviral vectors were employed to knockdown Huwel expression in L2.3 cells (Fig. 1C) as aforementioned. Accordingly, knockdown of Huwel expression was associated with significant reductions in the viability of L2.3 cells exposed 


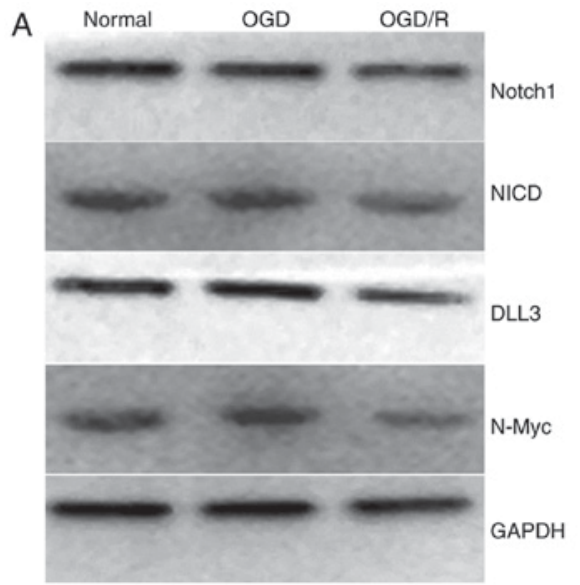

B
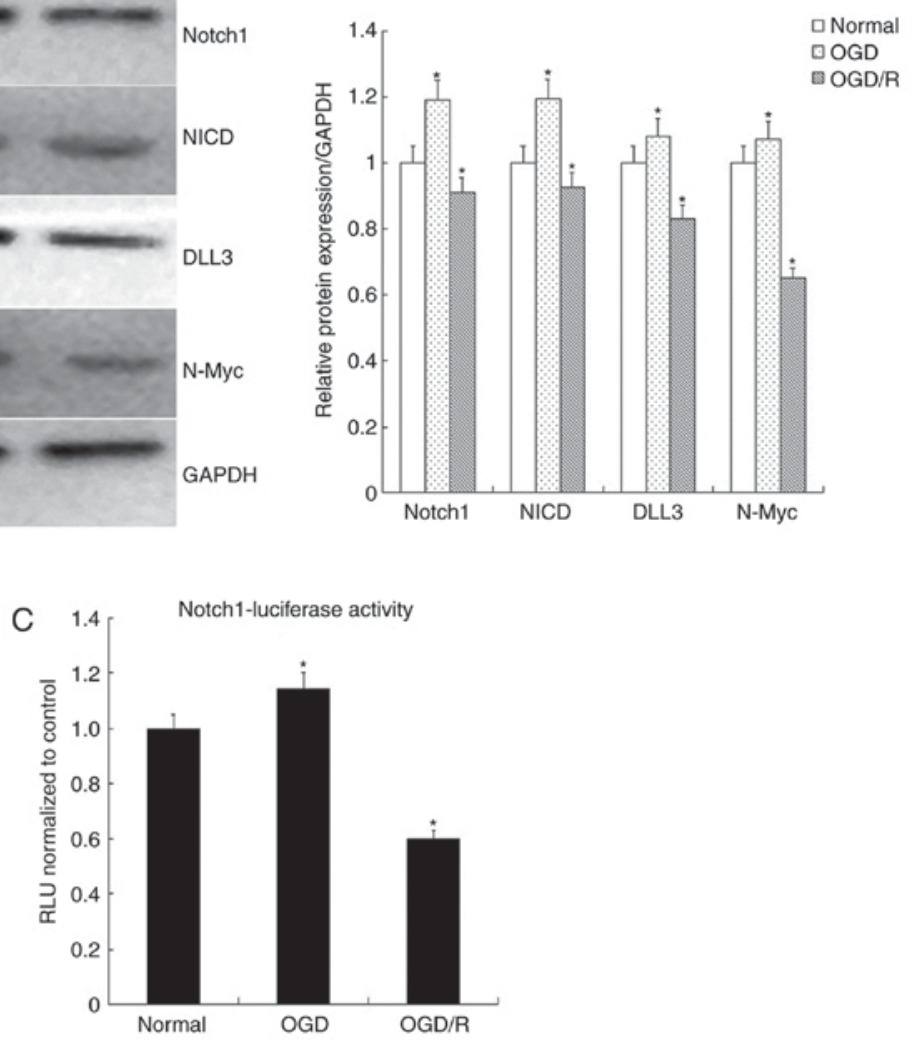

Figure 3. OGD/R inhibits N-Myc-DLL3-Notch signaling in L2.3 cells. (A) Representative western blot analysis for the expression of Notch1, NICD, DLL3, N-Myc and GAPDH in L2.3 cells exposed to OGD and OGD/R. (B) Quantification of western blot analysis presented in (A); expression levels were normalized to that of GAPDH. Three independent experiments were performed in triplicate. " $\mathrm{P}<0.05$ vs. the normal control. (C) L2.3 cells transfected with a Notch1-luciferase reporter plasmid were cultured under normal conditions or exposed to OGD for $6 \mathrm{~h}$ or OGD/R. The graph reports mean \pm the standard error. Data were obtained from three independent experiments. " $\mathrm{P}<0.05$ vs. the normal control. DLL3, Delta-like 3; NICD, Notch intracellular domain; OGD, oxygen-glucose deprivation; OGD/R, OGD for $6 \mathrm{~h}$ and restoration for $16 \mathrm{~h}$.

to OGD (Fig. 1D); LDH release was significantly elevated compared with in OGD control and OGD control shRNA cells (Fig. 1E). The data indicated that Huwe1 may be required to maintain L2.3 cell viability following the onset of OGD. To further evaluate whether N-Myc is involved in Huwel-mediated survival of L2.3 cells during OGD, the cell viability and LDH release in N-Myc-silenced L2.3 cells were determined. The results revealed that the downregulation of $\mathrm{N}-\mathrm{Myc}$ expression reduced LDH release and increased cell viability compared with in the normal control and OGD control shRNA groups (Fig. 1D and E).

Huwel knockdown induces nestin expression and the proliferation of $L 2.3$ cells. The present study analyzed the expression of nestin and MAP2 in L2.3 cells to determine whether cell proliferation led to cell differentiation. L2.3 cells underwent expansion for 5 days under normal condition or following OGD, and were stained with neural precursor cell marker nestin (green), neuronal marker MAP2 (red) and DAPI (blue). As presented in Fig. 2A and B, a significant increase in the number of $\mathrm{MAP} 2^{+}$cells was detected following OGD exposure compared with in the normal control conditions. Knockdown of Huwe1 expression induced a significant increase in the percentage of nestin ${ }^{+}$cells and a decrease in $\mathrm{MAP}^{+}$precursor cells (35) under normal and OGD conditions.
To determine whether the reduced viability of Huwe1-silenced L2.3 cells was due to the inhibition of proliferation, BrdU incorporation assays were conducted. The results of the present study revealed that $\mathrm{BrdU}^{+}$cells were more abundant in the control than under the OGD condition; notably fewer $\mathrm{BrdU}^{+}$. A significantly greater number of Huwe1-silenced cells were observed in OGD condition compared with in normal conditions (Fig. 2C). This indicated that, under normal conditions, a higher percentage of actively dividing cells may be detected. The results were consistent with the onset of cell proliferation, suggesting that Huwel may inhibit the proliferation in L2.3 cells.

OGD/restoration $(O G D / R)$ inhibits $N$-Myc-DLL3-Notch signaling in L2.3 cells. The potential mechanisms underlying the effects of Huwe1 in the neuronal differentiation of L2.3 cells were investigated in the present study. As presented in Fig. 1A, the expression levels of Huwel began to increase significantly after $16 \mathrm{~h}$ following the restoration of normal conditions. Therefore, $16 \mathrm{~h}$ was selected as the duration of restoration for the normal culture conditions. The results demonstrated that the expression levels of Notch1, NICD, DLL3 and N-Myc were significantly increased following exposure to OGD for $6 \mathrm{~h}$ and decreased after restoration for $16 \mathrm{~h}(\mathrm{OGD} / \mathrm{R})$ compared with in the normal control (Fig. 3A and B). The results suggested that OGD/R may inhibit Notch signaling. 

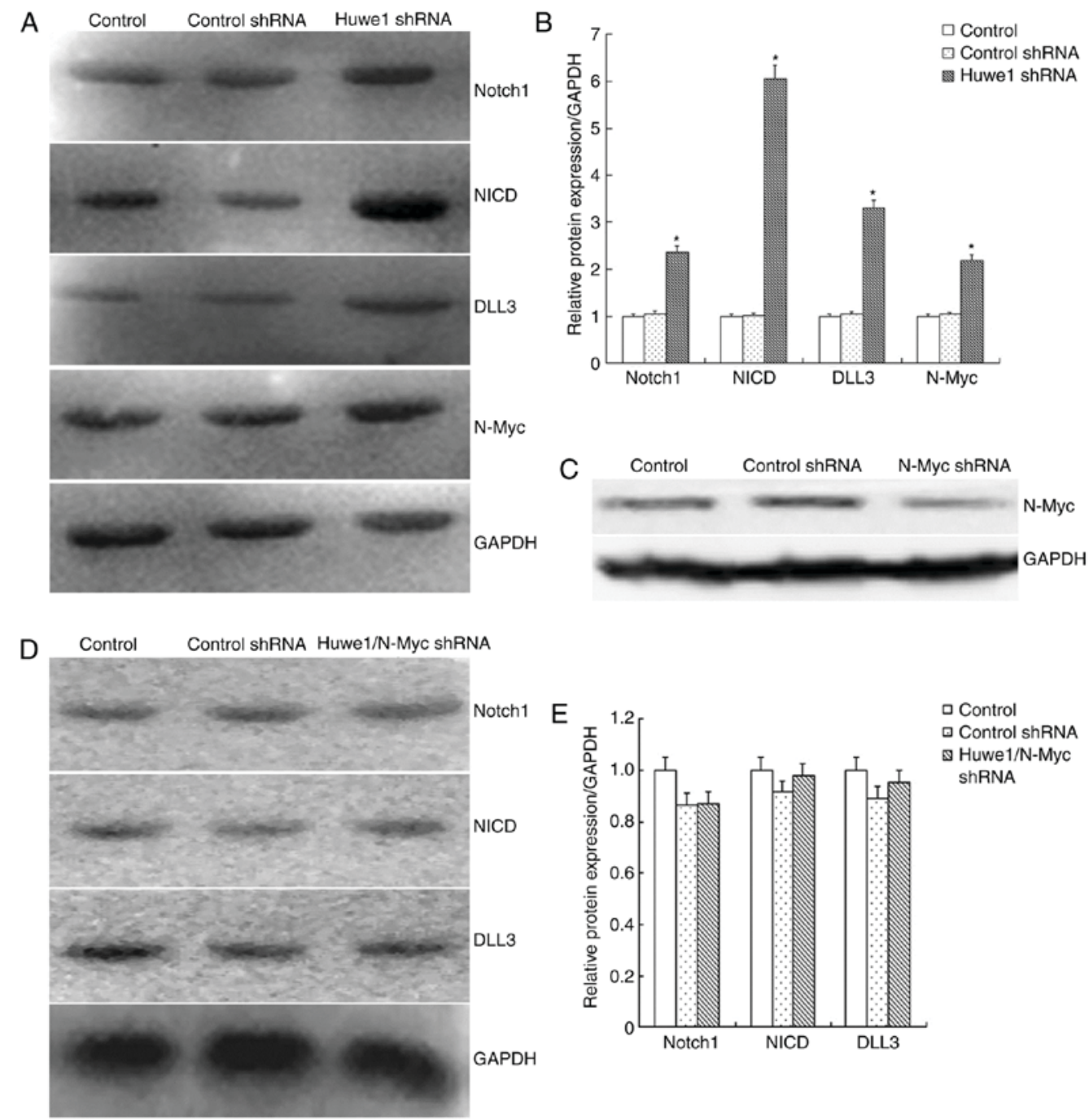

Figure 4. Huwe1 mediates the survival of L2.3 cells via the N-Myc-Notch1 signaling pathway during oxygen-glucose deprivation and restoration. (A) Representative western blot analysis for the expression of Notch1, NICD, DLL3, N-Myc and GAPDH in L2.3 cells transduced with viral particles overexpressing Huwe1 shRNA. (B) Quantification of western blot analysis presented in (A); expression levels were normalized to that of GAPDH. Three independent experiments were performed in triplicate. "P $<0.05$ vs. the control and control shRNA groups. (C) N-Myc protein levels measured in control L2.3 cells and L2.3 cells transduced with viral particles overexpressing control shRNA or N-Myc shRNA. (D) Representative western blotting for the expression of Notch1, NICD, DLL3, and GAPDH of L2.3 cells transduced with viral particles overexpressing Huwe1 shRNA and N-Myc shRNA. (E) Quantification of western blot analysis presented in (D); expression levels were normalized to that of GAPDH. Data are presented as the mean \pm standard error. Three independent experiments were performed in triplicate. "P<0.05 vs. the control and control shRNA groups. DLL3, Delta-like 3; NICD, Notch intracellular domain Huwe1, E3 ubiquitin protein ligase; NICD, Notch intracellular domain; shRNA, short hairpin RNA.

Additionally, Notch1-transcriptional activity was analyzed via a luciferase reporter assay, which revealed a significant decrease in Notch1 activation when L2.3 cells were exposed to OGD/R compared with in the normal control (Fig. 3C). These results further indicated that Notch signaling may be associated with cell fate.

Huwel mediates the survival of L2.3 cells via the N-Myc-Notch1 signaling pathway during $O G D$ and restoration. To evaluate whether Huwe1 affects the Notch1 signaling pathway, Huwel was downregulated in L2.3 cells, which were exposed to OGD for $6 \mathrm{~h}$ and restoration for $16 \mathrm{~h}$. The results demonstrated that N-Myc and the components of the Notch1 signaling pathway, including Notch1, NICD and DLL3 were significantly upregulated following the knockdown of Huwel compared with in the control groups (Fig. 4A and B). Additionally, knockdown of N-Myc expression in L2.3 cells was conducted (Fig. 4C), which revealed that the expression levels of the Notch1 signaling pathway components were not altered following knockdown of both Huwe1 and N-Myc expression (Fig. 4D and E). These results indicated that Huwel may require N-Myc to suppress the activation of the Notch1 signaling in L2.3 cells during OGD and the restoration of normal conditions.

\section{Discussion}

To the best of our knowledge, the present study is the first to report the protective role of Huwel in L2.3 cells under the OGD condition. Specifically, Huwel was observed to rescue L2.3 cells from OGD-induced injury by inhibiting proliferation and inducing neuronal differentiation. Subsequently, its effects on the downstream N-Myc-Delta-like 3-Notch1 signaling pathway were investigated to explore the underlying mechanisms. Mechanistically, it was demonstrated that Huwe1 mediated 
the survival of L2.3 cells via inhibition of the N-Myc-Notch1 signaling axis in the present study. Thus, in response to OGD and the restoration of normal conditions, Huwel was proposed to inhibit the N-Myc-Notch1 signaling axis and induce the differentiation of L2.3 cells in the present study. In addition, the effects of Huwe1 on Notch1 signaling were notably abolished via the knockdown of N-Myc. Therefore, the findings of the present study indicated that the Huwe1-N-Myc-Notch1 axis may be a novel neuroprotective pathway associated with ischemic stroke.

Huwel is important for neurogenesis (30); however, the biological function of Huwel in neurological diseases remains unknown (36). The present study reported that Huwel served a role in the survival of L2.3 cells under the OGD condition, which suggests Huwel as a potential target in the treatment of ischemic stroke. Consistent with the role of Huwel on the transition from NSCs to differentiated neurons, Huwel may improve the neurobehavioral outcomes following ischemic brain injury by enhancing neuronal differentiation and rescuing cells from OGD-induced insults. Previous studies have reported that Huwe1 acts via the N-Myc-DLL3-Notch1 signaling pathway during neural development $(27,30)$. Huwel was reported to suppress the N-Myc-DLL3 cascade associated with the initiation of neurogenesis in the developing brain, and negatively regulated the expression of DLL3 in an N-Myc-dependent manner, and the activation Notch1, a transmembrane receptor on the surface of neural progenitors, was proposed to be involved in NSC maintenance $(37,38)$. When activated by the ligands of neighboring cells, NICD translocates to the nucleus and activates transcription (39). In the developing brain, activated Notch signaling maintains the state of NSCs by promoting the proliferation of neural progenitors and inhibiting the differentiation progenitor cells into neurons (40). In support of this, a study indicated that attenuation of Notch signaling promoted the differentiation of neural progenitors in the subacute phase following ischemia (41). In conclusion, Huwe1 may protect neural progenitors L2.3 cells from injury associated with OGD and the restoration of normal conditions; however, further investigation is required to evaluate the pathological mechanism underlying the protective effects of Huwel in the acute phase of stroke.

\section{Acknowledgements}

Not applicable.

\section{Funding}

The present study was supported by the National Natural Science Foundation of China (grant nos. 81401238, 81330016 and 81630038), the Ministry of Education of China (grant nos. 313037 and 20110181130002), the State Commission of Science Technology of China (grant no. 2012BAI04B04), the Science and Technology Bureau of Sichuan Province (grant nos. 2012SZ0010, 2014SZ0149 and 2016JY0028), and the Clinical Discipline Program (Neonatology) of the Ministry of Health of China (grant no. 1311200003303).

\section{Availability of data and materials}

The datasets used and/or analyzed during the current study are available from the corresponding author on reasonable request.

\section{Authors' contributions}

XJ, JY and WX performed the experiments and analyzed the data. HL and YQ conducted the cell culture and molecular pathway experiments. HY and YT analyzed the resulting data and drafted the manuscript. All authors were responsible for drafting the manuscript, and read and approved the final version.

\section{Ethics approval and consent to participate}

Not applicable.

\section{Patient consent for publication}

Not applicable.

\section{Competing interests}

The authors declare that they have no competing interests.

\section{References}

1. Zhou L, Li F, Xu HB, Luo CX, Wu HY, Zhu MM, Lu W, Ji X, Zhou QG and Zhu DY: Treatment of cerebral ischemia by disrupting ischemia-induced interaction of nNOS with PSD-95. Nat Med 16: 1439-1443, 2010

2. Miclescu A, Sharma HS, Martijn C and Wiklund L: Methylene blue protects the cortical blood-brain barrier against ischemia/reperfusion-induced disruptions. Crit Care Med 38: 2199-2206, 2010

3. Lu P, Woodruff G, Wang Y, Graham L, Hunt M, Wu D, Boehle E, Ahmad R, Poplawski G, Brock J, et al: Long-distance axonal growth from human induced pluripotent stem cells after spinal cord injury. Neuron 83: 789-796, 2014.

4. Kärkkäinen V, Pomeshchik Y, Savchenko E, Dhungana H, Kurronen A, Lehtonen S, Naumenko N, Tavi P, Levonen AL, Yamamoto $\mathrm{M}$, et al: Nrf2 regulates neurogenesis and protects neural progenitor cells against $A \beta$ toxicity. Stem Cells 32: 1904-1916, 2014

5. Sabelström H, Stenudd M, Réu P, Dias DO, Elfineh M,Zdunek S, Damberg P, Göritz C and Frisén J: Resident neural stem cells restrict tissue damage and neuronal loss after spinal cord injury in mice. Science 342: 637-640, 2013.

6. Klempin F, Marr RA and Peterson DA: Modification of pax6 and olig2 expression in adult hippocampal neurogenesis selectively induces stem cell fate and alters both neuronal and glial populations. Stem Cells 30: 500-509, 2012.

7. Covey MV, Streb JW, Spektor R and Ballas N: REST regulates the pool size of the different neural lineages by restricting the generation of neurons and oligodendrocytes from neural stem/progenitor cells. Development 139: 2878-2890, 2012.

8. Burns AJ, Goldstein AM, Newgreen DF, Stamp L, Schäfer KH, Metzger M, Hotta R, Young HM, Andrews PW, Thapar N, et al: White paper on guidelines concerning enteric nervous system stem cell therapy for enteric neuropathies. Dev Biol 417: 229-251, 2016.

9. Goldman S: Stem and progenitor cell-based therapy of the human central nervous system. Nat Biotechnol 23: 862-871, 2005.

10. Rafalski VA, Ho PP, Brett JO, Ucar D, Dugas JC, Pollina EA, Chow LM, Ibrahim A, Baker SJ, Barres BA, et al: Expansion of oligodendrocyte progenitor cells following SIRT1 inactivation in the adult brain. Nat Cell Biol 15: 614-624, 2013.

11. Bonnamain V, Neveu I and Naveilhan P: Neural stem/progenitor cells as a promising candidate for regenerative therapy of the central nervous system. Front Cell Neurosci 6: 17, 2012.

12. Felling RJ, Snyder MJ, Romanko MJ, Rothstein RP, Ziegler AN, Yang Z, Givogri MI, Bongarzone ER and Levison SW: Neural stem/progenitor cells participate in the regenerative response to perinatal hypoxia/ischemia. J Neurosci 26: 4359-4369, 2006.

13. Zelentsova K, Talmi Z, Abboud-Jarrous G, Sapir T, Capucha T, Nassar M and Burstyn-Cohen T: Protein S regulates neural stem cell quiescence and neurogenesis. Stem Cells 35: 679-693, 2017. 
14. Liu M, Guan Z, Shen Q, Flinter F, Domínguez L, Ahn JW, Collier DA, O'Brien T and Shen S: Ulk4 regulates neural stem cell pool. Stem Cells 34: 2318-2331, 2016.

15. Venkatesh K, Reddy LVK, Abbas S, Mullick M, Moghal ETB, Balakrishna JP and Sen D: NOTCH signaling is essential for maturation, self-renewal, and tri-differentiation of in vitro derived human neural stem cells. Cell Reprogram 19: 372-383, 2017.

16. Georges P, Boissart C, Poulet A, Peschanski M and Benchoua A: Protein kinase-A inhibition is sufficient to support human neural stem cells self-renewal. Stem Cells 33: 3666-3672, 2015.

17. Swartling FJ, Savov V, Persson AI, Chen J, Hackett CS, Northcott PA, Grimmer MR, Lau J, Chesler L, Perry A, et al: Distinct neural stem cell populations give rise to disparate brain tumors in response to N-MYC. Cancer Cell 21: 601-613, 2012.

18. Zinin N, Adameyko I, Wilhelm M, Fritz N, Uhlén P, Ernfors P and Henriksson MA: MYC proteins promote neuronal differentiation by controlling the mode of progenitor cell division. EMBO Rep 15: 383-391, 2014.

19. Knoepfler PS, Cheng PF and Eisenman RN: N-myc is essential during neurogenesis for the rapid expansion of progenitor cell populations and the inhibition of neuronal differentiation. Genes Dev 16: 2699-2712, 2002

20. Androutsellis-Theotokis A, Leker RR, Soldner F, Hoeppner DJ, Ravin R, Poser SW, Rueger MA, Bae SK, Kittappa R and McKay RD: Notch signalling regulates stem cell numbers in vitro and in vivo. Nature 442: 823-826, 2006.

21. Mizutani K, Yoon K, Dang L, Tokunaga A and Gaiano N: Differential Notch signalling distinguishes neural stem cells from intermediate progenitors. Nature 449: 351-355, 2007.

22. Aguirre A, Rubio ME and Gallo V: Notch and EGFR pathway interaction regulates neural stem cell number and self-renewal. Nature 467: 323-327, 2010.

23. Ramasamy SK and Lenka N: Notch exhibits ligand bias and maneuvers stage-specific steering of neural differentiation in embryonic stem cells. Mol Cell Biol 30: 1946-1957, 2010.

24. Zhong Q, Gao W, Du F and Wang X: Mule/ARF-BP1, a BH3-only E3 ubiquitin ligase, catalyzes the polyubiquitination of Mcl-1 and regulates apoptosis. Cell 121: 1085-1095, 2005

25. Chen D, Kon N, Li M, Zhang W, Qin J and Gu W: ARF-BP1/Mule is a critical mediator of the ARF tumor suppressor. Cell 121: 1071-1083, 2005.

26. Bernassola F, Karin M, Ciechanover A and Melino G: The HECT family of E3 ubiquitin ligases: Multiple players in cancer development. Cancer Cell 14: 10-21, 2008.

27. Zhao X, Heng JI, Guardavaccaro D, Jiang R, Pagano M, Guillemot F, Iavarone A and Lasorella A: The HECT-domain ubiquitin ligase Huwel controls neural differentiation and proliferation by destabilizing the N-Myc oncoprotein. Nat Cell Biol 10: 643-653, 2008.

28. Leboucher GP, Tsai YC, Yang M, Shaw KC, Zhou M, Veenstra TD, Glickman MH and Weissman AM: Stress-induced phosphorylation and proteasomal degradation of mitofusin 2 facilitates mitochondrial fragmentation and apoptosis. Mol Cell 47: 547-557, 2012.
29. Hao Z, Duncan GS, Su YW, Li WY, Silvester J, Hong C, You H, Brenner D, Gorrini C, Haight J, et al: The E3 ubiquitin ligase Mule acts through the ATM-p53 axis to maintain B lymphocyte homeostasis. J Exp Med 209: 173-186, 2012.

30. Zhao X, D' Arca D, Lim WK, Brahmachary M, Carro MS Ludwig T, Cardo CC, Guillemot F, Aldape K, Califano A, et al: The N-Myc-DLL3 cascade is suppressed by the ubiquitin ligase Huwel to inhibit proliferation and promote neurogenesis in the developing brain. Dev Cell 17: 210-221, 2009.

31. Li H, Babiarz J, Woodbury J, Kane-Goldsmith N and Grumet M: Spatiotemporal heterogeneity of CNS radial glial cells and their transition to restricted precursors. Dev Biol 271: 225-238, 2004.

32. Li H, Han YR, Bi C, Davila J, Goff LA, Thompson K, Swerdel M, Camarillo C, Ricupero CL, Hart RP, et al: Functional differentiation of a clone resembling embryonic cortical interneuron progenitors. Dev Neurobiol 68: 1549-1564, 2008.

33. Schroers R, Davis CM, Wagner HJ and Chen SY: Lentiviral transduction of human T-lymphocytes with a RANTES intrakine inhibits human immunodeficiency virus type 1 infection. Gene Ther 9: 889-897, 2002

34. Zeng W, Tong Y, Li H, Luo R and Mao M: P2X7 receptor modulation of the viability of radial glial clone L2.3 cells during hypoxic-ischemic brain injury. Mol Med Rep 5: 1357-1361, 2012.

35. Maddodi N, Bhat KM, Devi S, Zhang SC and Setaluri V: Oncogenic BRAFV600E induces expression of neuronal differentiation marker MAP2 in melanoma cells by promoter demethylation and down-regulation of transcription repressor HES1. J Biol Chem 285: 242-254, 2010.

36. Zhou J, Liu Q, Mao M and Tong Y: Huwe1 as a therapeutic target for neural injury. Genet Mol Res 13: 4320-4325, 2014.

37. Benner EJ, Luciano D, Jo R, Abdi K, Paez-Gonzalez P, Sheng H, Warner DS, Liu C, Eroglu C and Kuo CT: Protective astrogenesis from the SVZ niche after injury is controlled by Notch modulator Thbs4. Nature 497: 369-373, 2013.

38. Mizeracka K, DeMaso CR and Cepko CL: Notch1 is required in newly postmitotic cells to inhibit the rod photoreceptor fate. Development 140: 3188-3197, 2013.

39. Altmann C, Vasic V, Hardt S, Heidler J, Häussler A, Wittig I, Schmidt MH and Tegeder I: Progranulin promotes peripheral nerve regeneration and reinnervation: Role of notch signaling. Mol Neurodegener 11: 69, 2016.

40. Giachino C, Basak O, Lugert S, Knuckles P, Obernier K, Fiorelli R, Frank S, Raineteau O, Alvarez-Buylla A and Taylor V: Molecular diversity subdivides the adult forebrain neural stem cell population. Stem Cells 32: 70-84, 2014.

41. Oya S, Yoshikawa G, Takai K, Tanaka JI, Higashiyama S, Saito N, Kirino T and Kawahara N: Attenuation of Notch signaling promotes the differentiation of neural progenitors into neurons in the hippocampal CA1 region after ischemic injury. Neuroscience 158: 683-692, 2009. 